\title{
NK-1 Receptor Antagonists and Pruritus: Review of Current Literature
}

\author{
Marcelina Pojawa-Gołąb · Kamila Jaworecka · Adam Reich
}

Received: April 12, 2019 / Published online: June 12, 2019

(C) The Author(s) 2019

\section{ABSTRACT}

The discovery of the first neurokinin 1 (NK-1) receptor antagonist was a turning point in the prevention of chemotherapy-induced nausea and vomiting. The NK-1 antagonists are a novel class of drugs that possess antidepressant, anxiolytic, and antiemetic properties. Recently, clinicians have also described an anti-itch activity of NK-1 antagonists. We present herein results from currently available data on use of NK-1R antagonists in dermatology. For this purpose, a systemic electronic literature search of the PubMed and CINAHL databases, Cochrane Library, and clinicaltrials.gov website was performed. Based on currently available data, it can be concluded that NK-1 inhibitors show significant antipruritic potential for treatment of chronic pruritus in different dermatological conditions, but further studies are needed to establish the best indications and dosage of these drugs.

Enhanced digital features To view enhanced digital features for this article go to https://doi.org/10.6084/ m9.figshare.8197787.

M. Pojawa-Gołąb · K. Jaworecka · A. Reich (凹) Department of Dermatology, University of Rzeszów, Rzeszów, Poland

e-mail: adamandrzejreich@gmail.com
Keywords: Aprepitant; Cutaneous; NK-1 inhibitors; Orvepitant; Pruritus; Serlopitant; Skin; Tradipitant

\section{INTRODUCTION}

The NK-1 antagonists are a novel class of drugs that possess antidepressant, anxiolytic, and antiemetic properties. Recently, clinicians have also described their antipruritic activity. Aprepitant, the commercially available NK-1 inhibitor, is registered for treatment of emesis associated with anticancer chemotherapy [1]. In 2009 for the first time, it was first reported that orally given aprepitant effectively reduced pruritus in three patients with Sézary syndrome [2]. Subsequent case reports documented its potential antipruritic effect in prurigo nodularis [1], brachioradial pruritus [3], paraneoplastic pruritus [4], drug-induced pruritus [5], and cutaneous T-cell lymphoma [6]. Interestingly, aprepitant was also shown to exert antitumoral activity on a human melanoma cell line, suggesting other possible treatment indications $[7,8]$. These findings led to the development of new substances and the initiation of numerous randomized controlled clinical trials for various indications, including also chronic pruritus. We present herein a review of currently available data on use of NK-1R antagonists in dermatology, with special emphasis on their potential antipruritic activity. 


\section{METHODS}

\section{Data Sources and Study Selection}

A systematic electronic literature search of the PubMed database, CINAHL database, Cochrane Library, and clinicaltrials.gov was performed. The PICO criteria for the literature search are presented in Table 1. Index words included combinations of the following terms: NK-1 antagonists, NK-1 inhibitors, aprepitant, serlopitant, tradipitant, orvepitant, and NK-1 blockers coupled with dermatology, skin, cutaneous, and pruritus. All results were checked for relevance. The references of included studies were searched for additional articles.

Our search yielded a total of 389 results (with redundancy) containing the mentioned keywords. Ultimately, 18 clinical articles were included in this review (Fig. 1). Nonhuman studies or articles published in languages other than English were excluded. Case reports and review articles were also eliminated.

This article is based on previously conducted studies and does not contain any studies with human participants or animals performed by any of the authors.

Table 1 PICO criteria of included studies

\begin{tabular}{ll}
\hline Population & Patients suffering from pruritus of any age \\
Intervention & Treatment with any NK-1R inhibitor \\
Comparator & $\begin{array}{l}\text { Any comparator, including no treatment or } \\
\text { placebo or active treatment }\end{array}$ \\
Outcomes & Change in pruritus prevalence \\
& $\begin{array}{l}\text { Change in mean pruritus intensity } \\
\text { Change in patient-reported outcomes }\end{array}$ \\
& $\begin{array}{l}\text { From the beginning of the database entry } \\
\text { until } 24 \text { May 2019 }\end{array}$ \\
Rtudy & $\begin{array}{l}\text { comparison studies, cohort studies, } \\
\text { experimental studies (excluded: case } \\
\text { reports, review papers) }\end{array}$ \\
\hline
\end{tabular}

\section{Substance $P$ and Neurokinin 1 Receptor Antagonist in Relation to Pruritus}

Substance P (SP) is a member of the tachykinin family, which also includes neurokinin $\mathrm{A}$ (NKA), neurokinin B (NKB), hemokinin 1, neuropeptide- $\gamma(\mathrm{NK}-\gamma)$, neuropeptide $\mathrm{K}$ (NPK), and endokinins. SP has the highest affinity to neurokinin 1 receptor (NK-1R) and lowest to NK-2R and NK-3R [9]. SP is a key mediator in the skin with potent proinflammatory properties and, next to calcitonin gene-related peptide (CGRP), is the most prominent neuropeptide released by peptidergic neurons [1]. NK-1R, also known as tachykinin receptor 1 (TACR-1) or SP receptor, is expressed in the central nervous system (dorsal horn neurons that project to the thalamus or parabrachial nuclei) as well as in peripheral tissues. At the periphery, NK-1R can be found in muscles, gastrointestinal tract, genitourinary tract, pulmonary tissue, thyroid gland, and different types of immune cells, and in the skin on keratinocytes, epithelial cells of hair follicles, mast cells, fibroblasts, epidermal dendritic cells, and endothelial cells $[1,9]$. NK$1 \mathrm{R}$ is also present on human melanoma cells and can mediate the viability of tumor cells [7]. Many central and peripheral effects of SP are mediated by NK-1R; binding of SP to NK-1R on keratinocytes and fibroblasts stimulates secretion of interferon $\gamma$, interleukin (IL)- $1 \beta$, and IL-8 [9]. Activation of NK-1R on mast cells leads to degranulation and secretion of histamine, leukotriene B4, prostaglandin D2, tumor necrosis factor $\alpha$, and vascular endothelial growth factor (VEGF), while on vessels it induces vasodilatation and neurogenic inflammation with clinical symptoms including erythema, edema, and pruritus [1].

It has been suggested that SP plays a significant role in the pathogenesis of pruritus in several disorders such as psoriasis [10-12], atopic dermatitis [13], and cholestatic pruritus [14]. Increased NK-1R expression was reported on keratinocytes along with increased SP serum level in patients with chronic pruritus [15]. Moreover, increased density of dermal SP-positive nerve fibers was identified within the skin of patients suffering from atopic dermatitis and prurigo nodularis and in the skin of chronic 


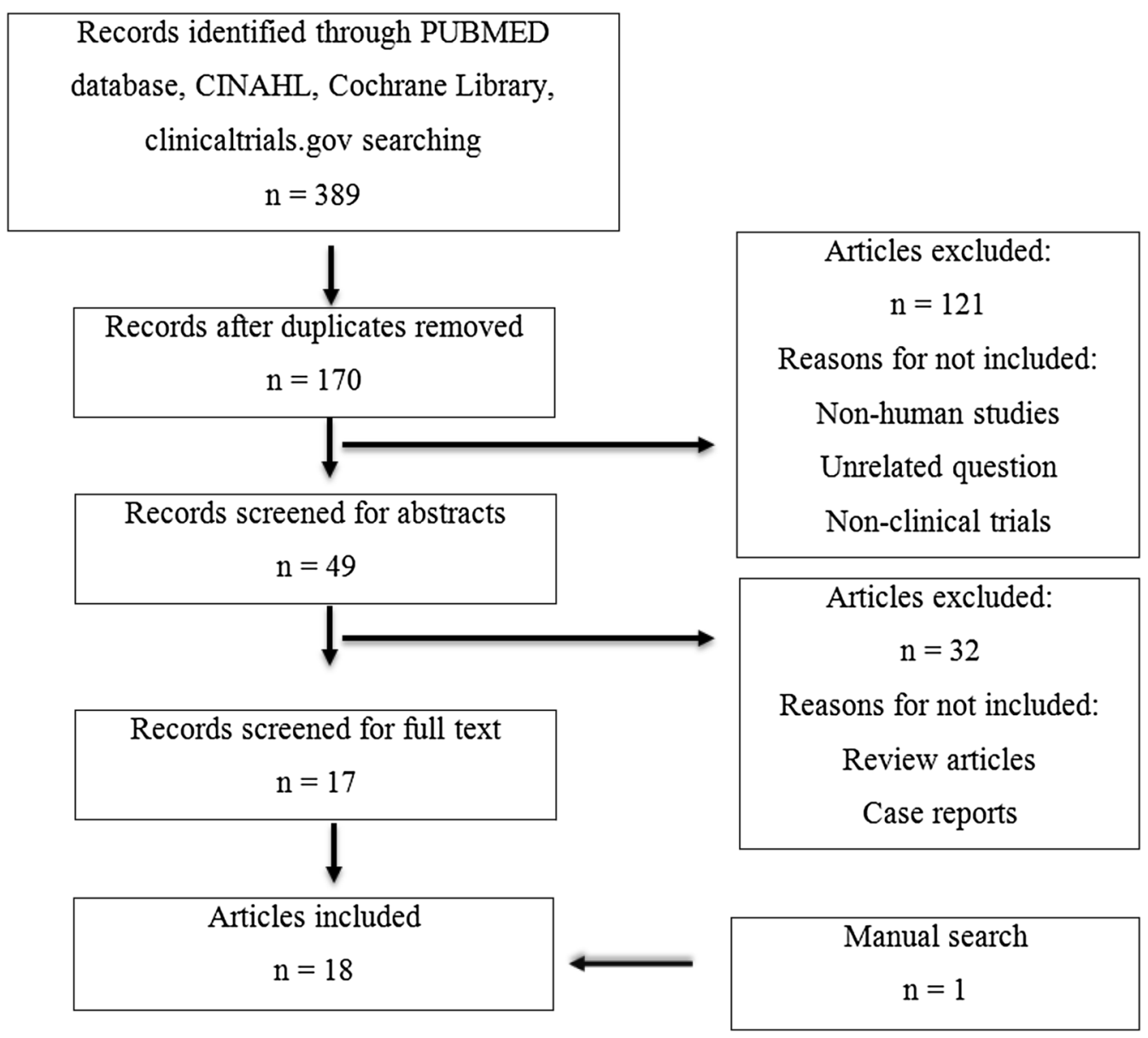

Fig. 1 Selection of publications for the analysis

pruritus patients [15-20]. Interestingly, SP plasma levels did not correlate with pruritus related to psoriasis, and even a significant negative correlation between pruritus severity and levels of SP was reported [21]. Ablation of NK-1expressing spinal neurons in rats inhibited acute and chronic itch, suggesting that spinothalamic and spinoparabrachial neurons play an important role in itch transmission. One may speculate that a similar situation also occurs in humans.

Nevertheless, better understanding of the role of SP in the pathomechanism of pruritus and a number of case series in which NK-1R inhibitors were successfully used to treat pruritus suggest that NK-1R antagonists might be a promising therapeutic option for acute and chronic itch. However, among the number of newly discovered NK-1R inhibitors, only a few (aprepitant, serlopitant, tradipitant, and orvepitant) have been investigated for pruritusassociated conditions. To the best of the authors' knowledge, the current review is the first to summarize data about the activity and efficacy of NK-1R inhibitors in dermatology.

\section{NK-1R INHIBITORS AND SKIN DISEASES}

\section{Aprepitant}

Aprepitant is a relatively old, selective, highaffinity antagonist of human NK-1R. Aprepitant has little or no affinity to serotonin (5-HT3), dopamine, and corticosteroid receptors. 
Aprepitant is able to cross the blood-brain barrier in humans. It was originally developed as an antidepressant, but clinical trials failed to demonstrate an antidepression effect at nontoxic dosing [22]. In animal studies, aprepitant was shown to centrally inhibit emesis induced by cytotoxic chemotherapeutic agents, such as cisplatin. The currently approved indications include chemotherapy-induced nausea and vomiting (CINV) and postoperative nausea and vomiting (PONV) [23-25]. The standard dosage for the approved indications is $125 \mathrm{mg}$ on the first day, and $80 \mathrm{mg} /$ day on the following 2 days. Aprepitant is metabolized by cytochrome P450 3A4 isoform (CYP3A4) and thus requires caution and careful monitoring during coadministration with other CYP3A4 substrates such as erlotinib, as it was shown to significantly decrease erlotinib clearance and increase its plasma concentration [26]. Some studies have documented its beneficial effects against pruritus in various conditions. Trials testing the antipruritic activity of aprepitant are summarized in Table 2. To date, the data on aprepitant in pruritus therapy remain conflicting.

Based on the description of two patients with metastatic non-small-cell lung cancer receiving erlotinib and successfully cured of pruritus after treatment with aprepitant [5], a single-center pilot study was designed to assess the efficacy of aprepitant for management of severe pruritus induced by biological anticancer drugs [27]. Forty-five outpatients with metastatic solid tumors treated with cetuximab, erlotinib, gefitinib, imatinib, or sunitinib were enrolled and treated with a short course of aprepitant. The study showed that aprepitant significantly decreased the severity of pruritus induced by biological anticancer treatments and could be a useful antipruritic agent both as the first-choice treatment or after failure of standard antipruritic therapy (Table 2) [27].

In another retrospective, analytical study, promising antipruritic activity of aprepitant was observed in 17 patients with cutaneous T-cell lymphoma. The authors claimed that the best antipruritic response was observed in lymphoma limited to skin (stages IB-IIB) and nonerythrodermic cutaneous lesions [28]. However, in a randomized, double-blind, placebo- controlled, crossover study on five patients with Sézary syndrome (NCT01625455), in which placebo or aprepitant was ingested daily for 7 days (125 $\mathrm{mg}$ on day 1 , followed by $80 \mathrm{mg}$ on days 2-7) followed by a 1-week washout, aprepitant even increased pruritus over the 7-day period [29]. These observations are contradictory to the significant antipruritic activity of aprepitant described in multiple case series of patients with Sézary syndrome or mycosis fungoides [2, 3, 30-33]. However, authors underlined that their study had several limitations, including small sample size (only five patients were enrolled) due to the rarity of the studied entity. Other reasons which might have an impact on the scoring of pruritus by visual analog scale (VAS) were different disease activity at baseline and external factors such as temperature and humidity [29].

In another open-label randomized trial, a total of 19 patients received $80 \mathrm{mg} /$ day aprepitant orally for 7 days in addition to topical treatment with hydrocortisone butyrate and a moisturizer; the control group received only topical treatment. Both study groups reported a highly significant improvement of atopic dermatitis severity according to SCORing of Atopic Dermatitis (SCORAD) and pruritus (according to VAS and scratching movement count), but no additional effect of oral aprepitant was found [34]. The authors linked the very good therapy result to a high level of compliance with the treatment regimen and suggested that the lack of a beneficial effect of aprepitant was due to rather mild to moderate pruritus in studied patients [34].

The next pilot study showed significant relief of pruritus in 20 randomly selected patients suffering from refractory chronic itch [35]. Aprepitant $(80 \mathrm{mg}$ ) was given once daily for 3-13 days. The mean pruritus intensity reduced from $8.4 \pm 1.7$ points to $4.9 \pm 3.2$ points after treatment. Altogether, 16 (80\%) patients responded to short-term aprepitant monotherapy, and subjects with dermatological diseases such as atopic eczema and prurigo nodularis showed the best improvement [35]. Adverse events occurred in three patients (nausea, vertigo, and drowsiness in one each) and were mild [35]. However, these favorable effects have not 
Table 2 Summary of studies with aprepitant in patients with pruritus

\begin{tabular}{|c|c|c|c|c|c|}
\hline Study & Indication & $\begin{array}{l}\text { No. of } \\
\text { patients }\end{array}$ & Dosing regimen of aprepitant & Results & Comments \\
\hline Lönndahl et al. [34] & $\begin{array}{l}\text { Moderate-severe } \\
\text { atopic dermatitis }\end{array}$ & 39 patients & $\begin{array}{l}\text { Active treatment group } \\
(n=19): 80 \mathrm{mg} / \text { day } \\
\text { aprepitant orally for } \\
7 \text { days }+ \text { topical treatment } \\
\text { with hydrocortisone butyrate } \\
\text { and moisturizer } \\
\text { Control group }(n=20) \text { : } \\
\text { placebo }+ \text { topical treatment }\end{array}$ & $\begin{array}{l}\text { Both study groups showed a } \\
\text { highly significant } \\
\text { improvement in extent of } \\
\text { atopic dermatitis and } \\
\text { pruritus } \\
\text { Extent of disease measured by } \\
\text { objective SCORAD decreased } \\
\text { in aprepitant-treated group } \\
\text { from } 40.5 \pm 12.0 \text { to } \\
32 \pm 11.2 \text { and in control } \\
\text { group from } 37.0 \pm 11.3 \text { to } \\
26.7 \pm 14.7 \text { points. } \\
\text { Subjective SCORAD } \\
\text { decreased in aprepitant group } \\
\text { from } 49.0 \pm 14.1 \text { to } \\
38.1 \pm 12.6 \text { and in control } \\
\text { group from } 47.7 \pm 13.7 \text { to } \\
33.0 \pm 18.9 \text { points } \\
\text { Pruritus measured by VAS } \\
\text { reduced from } 5.5 \pm 2.1 \text { to } \\
3.8 \pm 2.2 \text { in aprepitant group } \\
\text { compared with reduction } \\
\text { from } 6.7 \pm 2.2 \text { to } 4.1 \pm 3.0 \\
\text { points in control group } \\
\text { No additive effect with oral } \\
\text { aprepitant compared with } \\
\text { standard topical treatment } \\
\text { alone was found }\end{array}$ & $\begin{array}{l}\text { Short-term treatment design } \\
\text { might limit the significance } \\
\text { of achieved results } \\
\text { Thirteen patients reported } \\
\text { adverse events: headache, } \\
\text { fatigue, dizziness, elevated } \\
\text { liver enzymes, palpitations, } \\
\text { dyspnea, obstipation, } \\
\text { stomachache, periocular } \\
\text { dermatitis, altered ability to } \\
\text { react, erectile dysfunction } \\
\text { Two male patients in the } \\
\text { treatment group interrupted } \\
\text { their participation in the } \\
\text { study due to dizziness, } \\
\text { impotence, and headache } \\
\text { (one case), and lack of } \\
\text { reactivity, dyspnea, and } \\
\text { palpitations (second case) } \\
\text { Scratching movements showed } \\
\text { a high level of deviation } \\
\text { from the mean, leading to } \\
\text { difficulties in comparing the } \\
\text { treatment and control } \\
\text { groups }\end{array}$ \\
\hline $\begin{array}{l}\text { Maroñas-Jiménez } \\
\text { et al. [28] }\end{array}$ & $\begin{array}{l}\text { Pruritus in primary } \\
\text { cutaneous T-cell } \\
\text { lymphoma }\end{array}$ & 17 patients & $\begin{array}{l}125 \mathrm{mg} \text { on day } 1,80 \mathrm{mg} \text { on } \\
\text { days } 2-3 \text { in a weekly or } \\
\text { biweekly repetition regimen }\end{array}$ & $\begin{array}{l}\text { PtGA (Patient's Global } \\
\text { Assessment) evaluations } \\
\text { demonstrated overall } \\
\text { response rate of } 84 \% \\
\text { NRS scores reduced from } 10 \\
\text { points at baseline for } \\
\text { stages IB-IIB to } 1 \text { point and } \\
\text { from } 9.3 \text { points for stages } \\
\text { III-IV to } 5.7 \text { points after } \\
1 \text { week of treatment } \\
\text { The best antipruritic response } \\
\text { was observed in lymphomas } \\
\text { limited to skin } \\
\text { (stages IB-IIB) and } \\
\text { nonerythrodermic cutaneous } \\
\text { lesions }\end{array}$ & $\begin{array}{l}\text { This study has serious } \\
\text { limitations, due to } \\
\text { retrospective design, limited } \\
\text { sample size, and } \\
\text { concomitant } \\
\text { administration of other } \\
\text { antipruritics } \\
\text { AEs: grade } 1 \text { self-limited } \\
\text { headache and a transitory } \\
\text { mild drowsiness }\end{array}$ \\
\hline $\begin{array}{l}\text { Ohanyan et al. [20] } \\
\text { (NCT01963793) }\end{array}$ & Chronic prurigo & 19 patients & $\begin{array}{l}\text { Topical aprepitant } 1 \% \text { gel on } \\
\text { one side of the body and } \\
\text { placebo vehicle (gel) on the } \\
\text { other side, applied twice daily } \\
\text { for } 28 \text { days }\end{array}$ & $\begin{array}{l}\text { Efficacy was not significantly } \\
\text { different between aprepitant } \\
\text { gel and the placebo gel } \\
\text { vehicle, as both groups } \\
\text { showed large (more than } \\
\text { expected) improvement in } \\
\text { pruritus intensity, with over } \\
50 \% \text { reduction, as measured } \\
\text { by VAS }\end{array}$ & $\begin{array}{l}17 \text { patients (89\%) experienced } \\
\text { mild and moderate local } \\
\text { AEs: most commonly pain } \\
\text { and irritation at the site of } \\
\text { administration ( } 75 \% \text { versus } \\
55 \% \text { in aprepitant versus } \\
\text { vehicle group, respectively) }\end{array}$ \\
\hline
\end{tabular}


Table 2 continued

\begin{tabular}{|c|c|c|c|c|c|}
\hline Study & Indication & $\begin{array}{l}\text { No. of } \\
\text { patients }\end{array}$ & Dosing regimen of aprepitant & Results & Comments \\
\hline $\begin{array}{l}\text { Santini et al. [27] } \\
\text { (NCT01683552) }\end{array}$ & $\begin{array}{l}\text { Severe pruritus } \\
\text { induced by } \\
\text { biological } \\
\text { anticancer drugs }\end{array}$ & 45 patients & $\begin{array}{l}125 \mathrm{mg} \text { on day } 1,80 \mathrm{mg} \text { on } \\
\text { day } 3,80 \mathrm{mg} \text { on day } 5\end{array}$ & $\begin{array}{l}\text { Severity of pruritus measured by } \\
\text { VAS decreased in refractory } \\
\text { group (patients refractory to } \\
\text { antipruritic drugs in the past) } \\
\text { from } 8.0 \text { points at baseline to } \\
1.0 \text { point after } 1 \text { week of } \\
\text { treatment, and in naive group } \\
\text { (patients naive to antipruritic } \\
\text { therapy) from } 8.0 \text { points at } \\
\text { baseline to } 0 \text { points after } \\
1 \text { week of treatment } \\
41 \text { out of } 45 \text { ( } 91 \% \text { ) patients } \\
\text { responded to aprepitant }\end{array}$ & $\begin{array}{l}\text { No toxic effects potentially } \\
\text { related to aprepitant } \\
\text { treatment occurred }\end{array}$ \\
\hline Ständer et al. [35] & $\begin{array}{l}\text { Refractory chronic } \\
\text { pruritus }\end{array}$ & 20 patients & $80 \mathrm{mg}$ once daily for $3-13$ days & $\begin{array}{l}\text { Severity of pruritus measured by } \\
\text { VAS reduced from } 8.4 \text { points } \\
(S D \pm 1.7) \text { at baseline to } 4.9 \\
\text { points }(S D \pm 3.2) \text { after } \\
\text { treatment with aprepitant } \\
16 \text { out of } 20(80 \%) \text { patients } \\
\text { responded to the therapy }\end{array}$ & $\begin{array}{l}\text { Patients with dermatological } \\
\text { diseases and patients aged } \\
\text { between } 36 \text { and } 60 \text { years } \\
\text { showed the best benefit } \\
\text { from the treatment } \\
\text { Men tended to respond better } \\
\text { than women } \\
\text { AEs occurred in three patients } \\
\text { and were mild: nausea, } \\
\text { vertigo, drowsiness }\end{array}$ \\
\hline $\begin{array}{l}\text { Tsanakas et al. [36] } \\
\text { (EudraCT no. } \\
\text { 2013-001601- } \\
85 \text { ) }\end{array}$ & $\begin{array}{l}\text { Antihistamine- } \\
\text { refractory } \\
\text { chronic nodular } \\
\text { prurigo }\end{array}$ & 58 patients & $\begin{array}{l}80 \mathrm{mg} / \text { day versus placebo } \\
\text { (crossover design) }\end{array}$ & $\begin{array}{l}\text { No significant differences found } \\
\text { between aprepitant treatment } \\
\text { and placebo for any of the } \\
\text { parameters investigated: } \\
\text { mean itch intensity, worst } \\
\text { itch, prurigo lesions, patients' } \\
\text { global assessment, quality of } \\
\text { life, patient benefit index, } \\
\text { anxiety and depression } \\
\text { scoring }\end{array}$ & $\begin{array}{l}\text { To date, the best designed trial } \\
\text { conducted on aprepitant } \\
\text { for treatment of pruritus }\end{array}$ \\
\hline Wallengren [39] & $\begin{array}{l}\text { Pruritus in chronic } \\
\text { skin disease } \\
\text { volunteers }\end{array}$ & $\begin{array}{l}13 \text { patients } \\
\text { with } \\
\text { various } \\
\text { skin } \\
\text { diseases }\end{array}$ & $\begin{array}{l}5 \% \text { topical aprepitant or vehicle } \\
\text { applied in a right-left study } \\
\text { design }\end{array}$ & $\begin{array}{l}\text { Mean VAS scores for pruritus } \\
\text { were } 4.5 \pm 2.0 \text { prior to } \\
\text { treatment with aprepitant, } \\
4.1 \pm 2.2 \text { after } 30 \mathrm{~min} \text {, and } \\
2.8 \pm 1.6 \text { after } 2 \mathrm{~h} \text {. The } \\
\text { corresponding values on the } \\
\text { vehicle-treated side were } \\
5.1 \pm 2.2,3.4 \pm 1.9 \text {, and } \\
2.8 \pm 1.9\end{array}$ & $\begin{array}{l}\text { A single topical application of } \\
5 \% \text { aprepitant failed to } \\
\text { inhibit pruritus in } 13 \\
\text { enrolled patients, despite } \\
\text { satisfactory absorption of } \\
\text { the drug }\end{array}$ \\
\hline Wallengren [39] & $\begin{array}{l}\text { Pruritus and } \\
\text { erythema } \\
\text { induced by } \\
\text { prick-test } \\
\text { reaction to } \\
\text { histamine in } \\
\text { nonatopic } \\
\text { healthy } \\
\text { volunteers }\end{array}$ & $\begin{array}{l}7 \text { healthy } \\
\text { nonatopic } \\
\text { volunteers }\end{array}$ & $\begin{array}{l}5 \% \text { topical aprepitant/vehicle } \\
\text { was applied to the volar } \\
\text { surface on the left and right } \\
\text { forearm, and left on for } \\
30 \text { min; thereafter cream was } \\
\text { wiped, and both forearms } \\
\text { were pricked with histamine }\end{array}$ & $\begin{array}{l}\text { Mean VAS scores for pruritus } \\
\text { induced by prick-test } \\
\text { reactions to histamine were } \\
4.3 \pm 3.4 \text { on aprepitant- } \\
\text { treated side and } 4.8 \pm 2.4 \text { on } \\
\text { vehicle-treated side }\end{array}$ & $\begin{array}{l}\text { A single topical application of } \\
5 \% \text { aprepitant failed to } \\
\text { inhibit clinical pruritus } \\
\text { when histamine was } \\
\text { pricked into the skin, } \\
\text { despite satisfactory } \\
\text { absorption of the drug }\end{array}$ \\
\hline $\begin{array}{l}\text { Wallengren and } \\
\text { Edvinsson [38] }\end{array}$ & $\begin{array}{l}\text { Pruritus associated } \\
\text { with prick-test } \\
\text { reactions }\end{array}$ & $\begin{array}{l}13 \text { healthy } \\
\text { nonatopic } \\
\text { volunteers }\end{array}$ & $\begin{array}{l}5 \% \text { aprepitant gel, } 1 \% \\
\text { telcagepant hydrogel, and } \\
\text { their respective vehicles were } \\
\text { applied to an area of } \\
4 \mathrm{~cm} \times 4 \mathrm{~cm} \text { on the volar } \\
\text { surface of the forearms } \\
\text { (blinded right-left protocol), } \\
\text { then histamine was pricked } \\
\text { on the pretreated areas and } \\
\text { on control areas of the skin }\end{array}$ & $\begin{array}{l}\text { The flare and weal as well as } \\
\text { pruritus induced by } \\
\text { histamine prick tests were } \\
\text { not significantly affected by } \\
\text { any of the pretreatments }\end{array}$ & $\begin{array}{l}\text { Study limited by small sample } \\
\text { size }\end{array}$ \\
\hline
\end{tabular}


Table 2 continued

\begin{tabular}{|c|c|c|c|c|c|}
\hline Study & Indication & $\begin{array}{l}\text { No. of } \\
\text { patients }\end{array}$ & Dosing regimen of aprepitant & Results & Comments \\
\hline $\begin{array}{l}\text { Wallengren and } \\
\text { Edvinsson [38] }\end{array}$ & $\begin{array}{l}\text { Pruritus associated } \\
\text { with patch test } \\
\text { reactions }\end{array}$ & 11 patients & $\begin{array}{l}\text { Patch tests with } 5 \% \text { nickel } \\
\text { sulfate in petrolatum were } \\
\text { performed on five locations } \\
\text { on the dorsal part of the } \\
\text { upper arms. After } 48 \mathrm{~h} \text {, the } \\
\text { patch tests were removed and } \\
\text { evaluated. Four test areas } \\
\text { were then covered with } 5 \% \\
\text { aprepitant gel, } 1 \% \\
\text { telcagepant hydrogel, or } \\
\text { respective vehicles and } \\
\text { removed after another } 24 \mathrm{~h}\end{array}$ & $\begin{array}{l}\text { None of the treatments } \\
\text { influenced the nickel patch } \\
\text { test-induced pruritus } \\
\text { Treatment with aprepitant and } \\
\text { its vehicle alone resulted in } \\
\text { potentiation of the infiltration } \\
\text { of nickel reactions compared } \\
\text { with test reactions obtained } \\
\text { after no treatment }\end{array}$ & $\begin{array}{l}\text { Study limited by small sample } \\
\text { size }\end{array}$ \\
\hline $\begin{array}{l}\text { Zic et al. [4] } \\
\quad \text { (NCT01625455) }\end{array}$ & $\begin{array}{l}\text { Pruritus in Sézary } \\
\text { syndrome }\end{array}$ & 5 patients & $\begin{array}{l}\text { Aprepitant: } 125 \mathrm{mg} \text { on day } 1 \text {, } \\
80 \mathrm{mg} \text { on days } 2-7 \text { versus } \\
\text { placebo given orally for } \\
7 \text { days }\end{array}$ & $\begin{array}{l}\text { Significant increase of pruritus } \\
\text { according to VAS during } \\
\text { aprepitant treatment } \\
\text { No change over } 7 \text { days of } \\
\text { treatment in placebo group } \\
\text { No change in quality of life in } \\
\text { either group }\end{array}$ & $\begin{array}{l}\text { Limitations due to difficulty in } \\
\text { patient recruitment and } \\
\text { small sample size }\end{array}$ \\
\hline
\end{tabular}

$A E$ adverse event, $N R S$ numerical rating scale, $V A S$ visual analog scale

been confirmed by the recently published results of a double-blind, placebo-controlled phase II study on patients with chronic nodular prurigo [36]. Fifty-eight patients were randomized to receive either oral aprepitant $80 \mathrm{mg}$ /day or placebo for 4 weeks. Next, following a 2 -week washout phase, patients were crossed over to receive the other treatment for 4 weeks. At the end of the trial, no significant differences were found between the aprepitant and placebo arm for any of the analyzed parameters (Table 2) [36].

Similar results were reported regarding topical application of aprepitant in chronic prurigo, in which a topical formulation of aprepitant $(10 \mathrm{mg} / \mathrm{g}$ gel) did not show superiority over vehicle in reducing itch intensity [20]. Interestingly, both patient groups showed large (more than expected, over 50\% reduction as measured by VAS) improvement in pruritus intensity [20]. The authors suggested that it is highly probable that decrease of pruritus intensity in one arm or leg resulted in perception of an overall reduction in pruritus intensity by the patient, as shown in itch relief through "mirror scratching" trials [37]. Moreover, they reported significant differences observed in scratch artifacts and crusting in aprepitanttreated but not placebo-treated skin, which further supports such a hypothesis [20]. Analyses of patients' blood samples showed that aprepitant effectively penetrated skin and was absorbed into the blood, but the blood levels were too low to have any systemic effects and did not correlate with VAS scores [20]. In another study, the effect of topically applied aprepitant and telcagepant (CGRP antagonist) was examined on immediate and delayed reactivity of the skin as well as on associated pruritus [38]. Neither the flare nor pruritus induced by histamine prick tests were affected by any of the treatments. Also, none of the treatments influenced the nickel patch test-induced pruritus. Treatment with aprepitant and its vehicle alone even resulted in a potentiating effect on the inflammatory infiltration upon nickel exposure compared with test reactions obtained after no treatment [38]. Further results with 5\% topical aprepitant application in clinical and experimental pruritus was obtained from a study in which single topical application of 5\% aprepitant gel failed to inhibit pruritus in 13 enrolled patients, as well as erythema and itch after histamine [39]. These results contradict the suggestion that aprepitant may prevent mast cell activation in skin [20,38].

In addition to the above-mentioned anti-itch activity, aprepitant elicits antitumor action by 
inducing apoptosis of tumor cells, an effect reported in different in vitro studies carried out in lung cancer, rhabdomyosarcoma, neuroblastoma, and larynx, gastric, and colon carcinoma cell lines [40-44]. NK-1R has also been detected in all analyzed human primary invasive malignant and metastatic melanomas [7]. Aprepitant at $10-60 \mu \mathrm{M}$ concentrations elicited cell growth inhibition in a concentration-dependent manner in all melanoma cell lines through NK-1R [7]. These data indicate that NK-1R antagonists could also be considered as potential candidate new antitumor drugs for human melanoma.

\section{Serlopitant}

Serlopitant was originally developed for treatment of overactive bladder [45]. Based on the role of NK-1R in pruritus $[46,47]$ and the good safety and tolerability of serlopitant in a phase 2 trial [45], a number of controlled trials testing its antipruritic efficacy have been planned, are ongoing, or have recently been completed with pending results (chronic pruritusNCT01951274, atopic dermatitisNCT02975206; chronic prurigo nodularisNCT03546816 and NCT02196324; plaque psoriasis-NCT03343639; epidermolysis bullosaNCT02654483). Three of the recent studies (NCT01951274, NCT02196324, and NCT03343639) confirmed a significant antipruritic efficacy of serlopitant. The another one, testing the efficacy of serlopitant in atopic dermatitis (NCT02975206), produced disappointing results.

The first study (NCT01951274) showed significant antipruritic efficacy of serlopitant compared with placebo in patients with chronic refractory pruritus. A total of 222 patients received three different doses of serlopitant $(0.25 \mathrm{mg}, 1 \mathrm{mg}$, or $5 \mathrm{mg})$ daily for 6 weeks. At week 6 , the mean percentage change from baseline VAS score was significantly greater in the serlopitant $1 \mathrm{mg}(p=0.022)$ and $5 \mathrm{mg}$ $(p=0.013)$ groups versus placebo. The study affirmed good tolerability of serlopitant; the most common treatment-emergent adverse events were somnolence and mild diarrhea [48].
Another phase 2 trial (NCT 02196324) evaluated the reduction of pruritus in patients with treatment-refractory prurigo nodularis [49]. Patients $(n=128)$ were divided into two groups, receiving $5 \mathrm{mg}$ serlopitant or placebo for 8 weeks. The average itch VAS scores significantly improved with serlopitant versus placebo at week 4 and 8 . In the serlopitant group, the mean percentage changes of average itch VAS score were $-22.8 \%,-31.2 \%$, and $-48.3 \%$ at weeks 2,4 , and 8 , respectively, and in the placebo group $-11.2 \%,-17.2 \%$, and $-26.3 \%$, respectively. Noteworthy, antipruritic effect was observed as early as 2 weeks after beginning treatment. The most frequent adverse events in the serlopitant group were nasopharyngitis, diarrhea, and fatigue [49].

In a study evaluating the efficacy and safety of serlopitant in treatment of pruritus associated with plaque psoriasis (NCT03343639), 206 patients with the diagnosis of plaque psoriasis covering $\leq 10 \%$ of body surface area, lasting for at least 6 months prior to randomization and suffering from severe pruritus, received serlopitant $5 \mathrm{mg}$ or placebo orally once daily. Patients were not allowed to use any other antipsoriatic therapy except bland emollients for the duration of the trial. A statistically significant reduction of pruritus based on a 4-point improvement responder analysis was observed: $33 \%$ of patients treated with serlopitant $5 \mathrm{mg}$ daily achieved a 4-point or greater improvement on the worst-itch numeric rating scale (WI-NRS) at week 8 compared with baseline (primary efficacy endpoint) versus $21 \%$ of patients treated with placebo $(p=0.028)$. Serlopitant was well tolerated, and no serious adverse events were reported related to the drug [50].

In contrast, a trial assessing two doses of serlopitant ( $1 \mathrm{mg} /$ day and $5 \mathrm{mg}$ /day versus placebo) in 484 patients with atopic dermatitis (NCT02975206) did not meet its primary endpoint (WI-NRS score reduction) [51]. In addition, the secondary endpoint was not statistically different between the serlopitanttreated group and placebo. However, this study confirmed the good tolerability and safety profile of serlopitant in patients with severe pruritus (Table 3) [51]. 
Table 3 Summary of studies with serlopitant, tradipitant, and orvepitant in pruritus patients

\begin{tabular}{|c|c|c|c|c|c|}
\hline Reference & $\begin{array}{l}\text { Drug/ } \\
\text { indication }\end{array}$ & $\begin{array}{l}\text { No. of } \\
\text { patients }\end{array}$ & Dosing regimen & Results & Comments \\
\hline $\begin{array}{l}\text { Yosipovitch et al. } \\
\text { (NCT01951274) } \\
{[48]}\end{array}$ & $\begin{array}{l}\text { Serlopitant/ } \\
\text { chronic } \\
\text { refractory } \\
\text { pruritus }\end{array}$ & $\begin{array}{l}222 \\
\text { patients }\end{array}$ & $\begin{array}{l}3 \text { different doses of } \\
\text { serlopitant: } \\
0.25 \mathrm{mg}, 1 \mathrm{mg} \text {, } \\
5 \mathrm{mg} \text { versus } \\
\text { placebo once } \\
\text { daily for } 6 \text { weeks }\end{array}$ & $\begin{array}{l}\text { At week } 6,43 \%, 38 \% \text {, and } \\
53 \% \text { of patients in the } \\
\text { serlopitant } 0.25 \mathrm{mg} \text {, } \\
1 \mathrm{mg} \text {, and } 5 \mathrm{mg} \text { dose } \\
\text { groups, respectively, } \\
\text { reported at least 4-point } \\
\text { decrease in average VAS } \\
\text { pruritus score versus } \\
26 \% \text { of placebo-treated } \\
\text { patients ( } p<0.05 \text { for } \\
1 \mathrm{mg} / \text { day and } 5 \mathrm{mg} / \text { day } \\
\text { serlopitant group versus } \\
\text { placebo) }\end{array}$ & $\begin{array}{l}\text { The most common } \\
\text { adverse events in } \\
\text { the active } \\
\text { treatment group } \\
\text { were somnolence } \\
\text { and diarrhea }\end{array}$ \\
\hline $\begin{array}{l}\text { Ständer et al. } \\
\text { (NCT02196324) } \\
{[49]}\end{array}$ & $\begin{array}{c}\text { Serlopitant/ } \\
\text { treatment- } \\
\text { refractory } \\
\text { prurigo } \\
\text { nodularis }\end{array}$ & $\begin{array}{l}128 \\
\text { patients }\end{array}$ & $\begin{array}{l}5 \mathrm{mg} / \text { day } \\
\text { serlopitant versus } \\
\text { placebo for } \\
8 \text { weeks }\end{array}$ & $\begin{array}{l}\text { Mean percentage changes } \\
\text { from baseline in mean } \\
\text { average itch VAS score } \\
\text { at week } 2,4 \text {, and } 8 \text { were } \\
-22.8 \%,-31.2 \% \text {, and } \\
-48.3 \% \text {, respectively, in } \\
\text { the serlopitant group } \\
\text { versus }-11.2 \% \text {, } \\
-17.2 \% \text {, and }-26.3 \% \text {, } \\
\text { respectively, in the } \\
\text { placebo group } \\
\text { (difference significant at } \\
\text { week } 4 \text { and } 8 \text { ) }\end{array}$ & $\begin{array}{l}\text { Antipruritic effect } \\
\text { was observed as } \\
\text { early as } 2 \text { weeks } \\
\text { after beginning } \\
\text { treatment } \\
\text { The most frequent } \\
\text { adverse events were } \\
\text { nasopharyngitis, } \\
\text { diarrhea, and } \\
\text { fatigue }\end{array}$ \\
\hline $\begin{array}{l}\text { NCT03343639 } \\
{[50]}\end{array}$ & $\begin{array}{l}\text { Serlopitant/ } \\
\text { pruritus } \\
\text { associated } \\
\text { with } \\
\text { plaque } \\
\text { psoriasis }\end{array}$ & $\begin{array}{l}206 \\
\text { patients }\end{array}$ & $\begin{array}{l}5 \mathrm{mg} / \text { day } \\
\text { serlopitant versus } \\
\text { placebo for } \\
8 \text { weeks }\end{array}$ & $\begin{array}{l}\text { Response of 4-point or } \\
\text { greater improvement of } \\
\text { WI-NRS at week } 8 \\
\text { achieved in } 33 \% \text { of } \\
\text { patients treated with } \\
\text { serlopitant and } 21 \% \text { of } \\
\text { patients treated with } \\
\text { placebo }(p<0.05)\end{array}$ & $\begin{array}{l}\text { No serious AEs } \\
\text { reported }\end{array}$ \\
\hline
\end{tabular}


Table 3 continued

\begin{tabular}{|c|c|c|c|c|c|}
\hline Reference & $\begin{array}{l}\text { Drug/ } \\
\text { indication }\end{array}$ & $\begin{array}{l}\text { No. of } \\
\text { patients }\end{array}$ & Dosing regimen & Results & Comments \\
\hline $\begin{array}{l}\text { NCT02975206 } \\
{[51]}\end{array}$ & $\begin{array}{l}\text { Serlopitant/ } \\
\text { atopic } \\
\text { dermatitis }\end{array}$ & $\begin{array}{l}484 \\
\text { patients }\end{array}$ & $\begin{array}{l}2 \text { different doses of } \\
\text { serlopitant: } \\
1 \mathrm{mg} / \text { day and } \\
5 \mathrm{mg} / \text { day versus } \\
\text { placebo }\end{array}$ & $\begin{array}{l}\text { Mean change of WI-NRS } \\
\text { from baseline to week } 6 \\
\text { was }-2.25 \pm 2.2 \text { in } \\
\text { serlopitant } 5 \mathrm{mg} / \text { day } \\
\text { and }-2.32 \pm 2.42 \text { in } \\
\text { serlopitant } 1 \mathrm{mg} / \text { day } \\
\text { versus }-2.01 \pm 2.21 \text { in } \\
\text { placebo group ( } p \mathrm{NS} \text { ) } \\
\text { Responder rate of } 4 \text {-point } \\
\text { or greater improvement } \\
\text { of WI-NRS at week } 6 \\
\text { was } 20.6 \% \text { in patients } \\
\text { treated with } 5 \text { mg/day } \\
\text { serlopitant and } 22.4 \% \text { in } \\
\text { patients treated with } \\
1 \text { mg/day serlopitant } \\
\text { versus } 16.5 \% \text { in patients } \\
\text { treated with placebo } \\
(p \text { NS) }\end{array}$ & $\begin{array}{l}\text { No serious AEs were } \\
\text { reported }\end{array}$ \\
\hline $\begin{array}{l}\text { NCT02004041 } \\
\quad[56]\end{array}$ & $\begin{array}{l}\text { Tradipitant/ } \\
\text { atopic } \\
\text { dermatitis }\end{array}$ & $\begin{array}{l}69 \\
\text { patients }\end{array}$ & $\begin{array}{l}50 \text { mg of tradipitant } \\
\text { versus placebo } \\
\text { given orally for } \\
4 \text { weeks }\end{array}$ & $\begin{array}{l}\text { Tradipitant was not } \\
\text { superior to placebo in } \\
\text { reducing itch intensity in } \\
\text { patients with atopic } \\
\text { dermatitis }\end{array}$ & \\
\hline $\begin{array}{l}\text { Heitman et al. } \\
\text { (NCT02651714) } \\
{[57]}\end{array}$ & $\begin{array}{l}\text { Tradipitant/ } \\
\text { atopic } \\
\text { dermatitis }\end{array}$ & $\begin{array}{l}168 \\
\text { patients }\end{array}$ & $\begin{array}{l}85 \text { mg tradipitant } \\
\text { versus placebo } \\
\text { administered } \\
\text { orally twice a day }\end{array}$ & $\begin{array}{l}\text { Subjects receiving } \\
\text { tradipitant showed } \\
\text { improvements on: the } \\
\text { Worst Itch VAS scale } \\
\text { compared with placebo } \\
\text { ( } 44.2 \text { versus } 30.6 ; \\
p=0.019) \\
\text { The total SCORAD index } \\
\text { compared with placebo } \\
(21.3 \text { versus } 13.6 ; \\
p=0.008) \\
\text { Objective SCORAD } \\
\text { compared with placebo } \\
\text { (13.3 versus } 7.2 ; \\
p=0.005)\end{array}$ & $\begin{array}{l}\text { No full report } \\
\text { available }\end{array}$ \\
\hline
\end{tabular}


Table 3 continued

\begin{tabular}{|c|c|c|c|c|c|}
\hline Reference & $\begin{array}{l}\text { Drug/ } \\
\text { indication }\end{array}$ & $\begin{array}{l}\text { No. of } \\
\text { patients }\end{array}$ & Dosing regimen & Results & Comments \\
\hline $\begin{array}{l}\text { EU-CTR2013 } \\
002763-25[55]\end{array}$ & $\begin{array}{l}\text { Orvepitant/ } \\
\text { EGFRi- } \\
\text { induced } \\
\text { intense } \\
\text { pruritus }\end{array}$ & $\begin{array}{l}27 \\
\text { patients }\end{array}$ & $\begin{array}{l}\text { Orvepitant } 10 \text { and } \\
30 \mathrm{mg} \text { versus } \\
\text { placebo given } \\
\text { once daily, orally } \\
\text { for } 4 \text { weeks }\end{array}$ & $\begin{array}{l}\text { Antipruritic effect of a } \\
\text { high-dose ( } 30 \mathrm{mg} \text { daily) } \\
\text { or low-dose ( } 10 \mathrm{mg} \\
\text { daily) regimen was not } \\
\text { confirmed }\end{array}$ & $\begin{array}{l}\text { Small numbers of } \\
\text { studied patients } \\
\text { and technical } \\
\text { problems limit the } \\
\text { reliability of } \\
\text { obtained data } \\
\text { Full report of the } \\
\text { trial has not been } \\
\text { published }\end{array}$ \\
\hline
\end{tabular}

$A E$ adverse event, $N S$ not significant, $V A S$ visual analog scale, WI-NRS Worst Itch Numerical Rating Scale

\section{Orvepitant and Tradipitant}

Orvepitant and tradipitant are other NK-1R antagonists tested for their antipruritic properties. Initially, orvepitant was developed as an antidepressant drug, but in spite of having some antidepressant properties, its efficacy was not good enough to continue further development $[52,53]$. However, data on animals suggested that orvepitant might possess antipruritic properties [54]. Subsequently, a trial was conducted to evaluate orvepitant efficacy in humans (10 and $30 \mathrm{mg}$ given orally once daily for 4 weeks) compared with placebo in reducing the intensity of epidermal growth factor receptor inhibitors (EGFRi)-induced pruritus. Importantly, neither a low-dose regimen (10 mg daily) nor a high-dose regimen (30 $\mathrm{mg}$ daily) showed a significant antipruritic effect (EUCTR2013 002763-25) (Table 3) [55].

Data on tradipitant also remain controversial. The dose of $50 \mathrm{mg}$ of tradipitant given orally for 4 weeks was not superior to placebo in reducing itch intensity in patients with atopic dermatitis (NCT02004041) [56]. However, in a subsequent study, in which a higher dose (85 mg) was administered for 8 weeks, significant antipruritic effect compared with placebo was recorded (NCT02651714) (Table 3) [57]. Another large study is ongoing (NCT03568331) and may provide further important data on the antipruritic efficacy of this drug against atopic itch [58].

\section{DISCUSSION}

NK-1R inhibitors have shown significant, albeit not uniform, anti-itch potential in the treatment of chronic pruritus present in different dermatological conditions. Interestingly, aprepitant also elicited in vitro antitumor activity by inducing apoptosis of melanoma cells, suggesting another potential indication of this drug that warrants further investigation. Studies evaluating topical use of aprepitant did not show its superiority versus placebo despite good absorption of the drug, but this may be due to predominant centrally mediated activity in the nervous system [20, 38, 39]. However, currently available studies have several limitations, such as small sample size, improper trial design, or too short therapy period, to draw valid conclusions for the future. Thus, larger, double-blind, placebo-controlled, parallel group designed trials with topical and oral NK-1R antagonists are needed to verify their possible usefulness.

In various trials with oral aprepitant, improvement of pruritus symptoms was observed, but the use of this drug may be limited by potential interactions with other drugs, especially those metabolized by CYP3A4, as strict monitoring and surveillance of drug 
plasma concentrations could be necessary [59]. So far, based on reports of almost 3000 people taking up to $300 \mathrm{mg}$ of oral aprepitant for up to 8 weeks, it is generally well tolerated over a long time period with no significant differences in adverse events versus placebo $[60,61]$. The trial with serlopitant in patients with pruritus and atopic dermatitis, in which neither the primary nor secondary end point was achieved (NCT02975206), indicates that further exploration of the antiinflammatory effects of NK-1R antagonists is needed. In contrast, serlopitant was effective in other types of pruritus, namely psoriatic itch, chronic refractory itch, and prurigo nodularis. A possible explanation for such discrepancies could be different pathogenesis and mechanisms involved in both inflammation and pruritus. It is possible that, in some conditions, SP is not a principal mediator of pruritus. In addition, the influence of polymorphism of the tachykinin receptor (TacR)-1 gene may be of importance [62].

\section{CONCLUSIONS}

In summary, based on studies publish to date, NK1R inhibitors seem to exhibit significant antipruritic activity and further studies are needed to define optimal dosing regiments to achieve longterm control of pruritus and better understand the pruritic states that will benefit most from NK-1R antagonists, as the pathomechanism may differ between various diseases. Pruritus remains one of the most bothersome subjective symptoms and can have a strong impact on quality of life. Effective therapy for patients suffering from chronic pruritus remains challenging, thus new therapies are urgently needed.

\section{ACKNOWLEDGEMENTS}

Funding. No funding or sponsorship was received for this study or publication of this article.
Authorship. All named authors meet the International Committee of Medical Journal Editors (ICMJE) criteria for authorship for this article, take responsibility for the integrity of the work as a whole, and have given their approval for this version to be published.

Disclosures. Marcelina Pojawa-Gołąb participated as investigator in clinical trials sponsored by AbbVie, and Leo Pharma. Kamila Jaworecka participated as investigator in clinical trials sponsored by AbbVie and Kymab Limited. Adam Reich has worked as a Consultant or Speaker for AbbVie, Bioderma, Celgene, Chema Elektromet, Eli Lilly, Galderma, Janssen, Leo Pharma, Medac, Menlo Therapeutics, Novartis, Pierre-Fabre, Sandoz and Trevi and participated as Principal Investigator or Subinvestigator in clinical trials sponsored by AbbVie, Drug Delivery Solutions Ltd, Galderma, Genentech, Janssen, Kymab Limited, Leo Pharma, Menlo Therapeutics, MetrioPharm, MSD, Novartis, Pfizer and Trevi.

Compliance with Ethics Guidelines. This article is based on previously conducted studies and does not contain any studies with human participants or animals performed by any of the authors.

Data Availability. Data sharing is not applicable to this article as no data sets were generated or analyzed during the current study.

Open Access. This article is distributed under the terms of the Creative Commons Attribution-NonCommercial 4.0 International License (http://creativecommons.org/licenses/ by-nc/4.0/), which permits any noncommercial use, distribution, and reproduction in any medium, provided you give appropriate credit to the original author(s) and the source, provide a link to the Creative Commons license, and indicate if changes were made. 


\section{REFERENCES}

1. Ständer S, Luger TA. NK-1 antagonists and itch. Handb Exp Pharmacol. 2015;226:237-55.

2. Duval A, Dubertret L. Aprepitant as an antipruritic agent? N Engl J Med. 2009;361:1415-6.

3. Booken N, Heck M, Nicolay JP, Klemke CD, Goerdt S, Utikal J. Oral aprepitant in therapy of refractory pruritus in erythrodermic cutaneous T-cell lymphoma. Br J Dermatol. 2011;164:665-7.

4. Vincenzi B, Fratto ME, Santini D, Tonini G. Aprepitant against pruritus in patients with solid tumors. Support Care Cancer. 2010;18:1229-30.

5. Vincenzi B, Tonini G, Santini D. Aprepitant for erlotinib-induced pruritus. $\mathrm{N}$ Engl J Med. 2010;363:397-8.

6. Ally MS, Gamba CS, Peng DH, Tang JY. The use of aprepitant in brachioradial pruritus. JAMA Dermatol. 2013;149:627-8.

7. Muñoz M, Rosso M, Robles-Frias MJ, et al. The NK-1 receptor is expressed in human melanoma and is involved in the antitumor action of the NK-1 receptor antagonist aprepitant on melanoma cell lines. Lab Investig. 2010;90:1259-69.

8. Ping F, Shang J, Zhou J, Song J, Zhang L. Activation of neurokinin-1 receptor by substance $\mathrm{P}$ inhibits melanogenesis in B16-F10 melanoma cells. Int J Biochem Cell Biol. 2012;44:2342-8.

9. Scholzen T, Armstrong CA, Bunnett NW, et al. Neuropeptides in the skin: interactions between the neuroendocrine and the skin immune systems. Exp Dermatol. 1998;272:81-96.

10. Nakamura M, Toyoda M, Morohashi M. Pruritogenic mediators in psoriasis vulgaris: comparative evaluation of itch-associated cutaneous factors. Br J Dermatol. 2003;149:718-30.

11. Chang SE, Han SS, Jung HJ, Choi JH. Neuropeptides and their receptors in psoriatic skin in relation to pruritus. Br J Dermatol. 2007;156:1272-7.

12. Kubanov AA, Katunina OR, Chikin VV. Expression of neuropeptides, neurotrophins, and neurotransmitters in the skin of patients with atopic dermatitis and psoriasis. Bull Exp Biol Med. 2015;159:318-22.

13. Hosokawa C, Takeuchi S, Furue M. Severity scores, itch scores and plasma substance $P$ levels in atopic dermatitis treated with standard topical therapy with oral olopatadine hydrochloride. J Dermatol. 2009;36:185-90.
14. Trivedi M, Bergasa NV. Serum concentrations of substance $P$ in cholestasis. Ann Hepatol. 2010;9:177-80.

15. Zeidler C, Ständer S. The pathogenesis of prurigo nodularis_-'super-itch' in exploration. Eur J Pain. 2016;20:37-40.

16. Abadía Molina F, Burrows NP, Jones RR, Terenghi $\mathrm{G}$, Polak JM. Increased sensory neuropeptides in nodular prurigo: a quantitative immunohistochemical analysis. Br J Dermatol. 1992;127:344-51.

17. Järvikallio A, Harvima IT, Naukkarinen A. Mast cells, nerves and neuropeptides in atopic dermatitis and nummular eczema. Arch Dermatol Res. 2003;295:2-7.

18. Haas S, Capellino S, Phan NQ, et al. Low density of sympathetic nerve fibers relative to substance P-positive nerve fibers in lesional skin of chronic pruritus and prurigo nodularis. J Dermatol Sci. 2010;58:193-7.

19. Yosipovitch G, Bernhard JD. Chronic pruritus. N Engl J Med. 2013;368:1625-34.

20. Ohanyan T, Schoepke N, Eirefelt S, et al. Role of substance $\mathrm{P}$ and its receptor neurokinin 1 in chronic prurigo: a randomized, proof-of-concept, controlled trial with topical aprepitant. Acta Derm Venereol. 2018;98:26-31.

21. Reich A, Orda A, Wiśnicka B, Szepietowski JC. Plasma neuropeptides and perception of pruritus in psoriasis. Acta Derm Venereol. 2007;87:299-304.

22. Devane CL. Substance P: new era, a new role. Pharmacotherapy. 2001;21:1061-9.

23. Hesketh PJ, Grunberg SM, Gralla RJ, et al. The oral neurokinin-1 antagonist aprepitant for the prevention of chemotherapy-induced nausea and vomiting: a multinational, randomized, double-blind, placebo-controlled trial in patients receiving highdose cisplatin. J Clin Oncol. 2003;21:4112-9.

24. Singh PM, Borle A, Rewari V, et al. Aprepitant for postoperative nausea and vomiting: a systematic review and meta-analysis. Postgrad Med J. 2016;92:87-98.

25. Dando TM, Perry C. Aprepitant: a review of its use in the prevention of chemotherapy-induced nausea and vomiting. Drugs. 2004;64:777-94.

26. Mir O, Blanchet B, Goldwasser F. More on aprepitant for erlotinib-induced pruritus. N Engl J Med. 2011;364:487.

27. Santini D, Vincenzi B, Guida FM, et al. Aprepitant for management of severe pruritus related to 
biological cancer treatments: a pilot study. Lancet Oncol. 2012;13:1020-4.

28. Maroñas-Jiménez L, Estrach T, Gallardo F, et al. Aprepitant improves refractory pruritus in primary cutaneous T-cell lymphomas: experience of the Spanish Working Group on Cutaneous Lymphomas. Br J Dermatol. 2018;178:e273-4.

29. Zic JA, Straka BT, McGirt LY, et al. Aprepitant for the treatment of pruritus in Sézary syndrome: a randomized crossover clinical trial. JAMA Dermatol. 2018;154:1221-2.

30. Ladizinski B, Bazakas A, Olsen EA. Aprepitant: a novel neurokinin-1 receptor/substance $P$ antagonist as antipruritic therapy in cutaneous T-cell lymphoma. J Am Acad Dermatol. 2012;67:e198-9.

31. Jiménez Gallo D, Albarrán Planelles C, Linares Barrios $\mathrm{M}$, et al. Treatment of pruritus in early-stage hypopigmented mycosis fungoides with aprepitant. Dermatol Ther. 2014;27:178-82.

32. Borja-Consigliere HA, López-Pestaña A, Vidal-Manceñido MJ, Tuneu-Valls A. Aprepitant in the treatment of refractory pruritus secondary to cutaneous T-cell lymphoma. Actas Dermosifiliogr. 2014;105:716-8.

33. Song JS, Tawa M, Chau NG, Kupper TS, LeBoeuf NR. Aprepitant for refractory cutaneous T-cell lymphoma-associated pruritus: four cases and a review of the literature. BMC Cancer. 2017;17:200.

34. Lönndahl L, Holst M, Bradley M, et al. Substance P antagonist aprepitant shows no additive effect compared with standardized topical treatment alone in patients with atopic dermatitis. Acta Derm Venereol. 2018;98:324-8.

35. Ständer S, Siepmann D, Herrgott I, et al. Targeting the neurokinin receptor 1 with aprepitant: a novel antipruritic strategy. PLoS One. 2010;5:e10968.

36. Tsianakas A, Zeidler C, Riepe C, et al. Aprepitant in anti-histamine-refractory chronic nodular prurigo: a multicentre, randomized, double-blind, placebocontrolled, cross-over, phase-II trial (APREPRU). Acta Derm Venereol. 2019;99:379-85.

37. Helmchen C, Palzer C, Munte TF, et al. Itch relief by mirror scratching. A psychophysical study. PLoS One. 2013;8:e82756.

38. Wallengren J, Edvinsson L. Topical non-peptide antagonists of sensory neurotransmitters substance $P$ and CGRP do not modify patch test and prick test reactions: a vehicle-controlled, double blind pilot study. Arch Dermatol Res. 2014;306:505-9.
39. Wallengren J. Topical aprepitant in clinical and experimental pruritus. Arch Dermatol. 2012;148:957-8.

40. Muñoz M, Rosso M, Pérez A, et al. Antitumoural action of the neurokinin-1-receptor antagonist L-733 060 and mitogenic action of substance P on human retinoblastoma cell lines. Investig Ophthalmol Vis Sci. 2005;46:2567-70.

41. Muñoz M, Rosso M, Coveñas R. The NK-1 receptor is involved in the antitumoural action of L-733060 and in the mitogenic action of substance $\mathrm{P}$ on human pancreatic cancer cell lines. Lett Drug Des Discov. 2006;3:323-9.

42. Muñoz M, Rosso M, Aguilar FJ, et al. NK-1 receptor antagonists induce apoptosis and counteract substance P-related mitogenesis in human laryngeal cancer cell line HEp-2. Investig New Drugs. 2008;26:111-8.

43. Rosso M, Robles-Frías MJ, Coveñas R, et al. The NK1 receptor is expressed in human primary gastric and colon adenocarcinomas and is involved in the antitumor action of L-733 060 and the mitogenic action of substance $\mathrm{P}$ on human gastrointestinal cancer cell lines. Tumor Biol. 2008;29:245-54.

44. Muñoz M, Pérez A, Coveñas R, et al. Antitumoural action of L-733 060 on neuroblastoma and glioma cell lines. Arch Ital Biol. 2004;142:105-12.

45. Frenkl TL, Zhu H, Reiss T, et al. A multicenter, double-blind, randomized, placebo-controlled trial of a neurokinin-1 receptor antagonist for overactive bladder. J Urol. 2010;184:616-22.

46. Bautista DM, Wilson SR, Hoon MA. Why we scratch an itch: the molecules, cells and circuits of itch. Nat Neurosci. 2014;17:175-82.

47. Ikoma A, Steinhoff M, Ständer S, et al. The neurobiology of itch. Nat Rev Neurosci. 2006;7:535-47.

48. Yosipovitch G, Stander S, Kerby MB. Serlopitant for the treatment of chronic pruritus: results of a randomized, multicenter, placebo-controlled phase 2 clinical trial. J Am Acad Dermatol. 2018;78:882-91.

49. Ständer S, Kwon P, Hirman J et al. Serlopitant reduced pruritus in patients with prurigo nodularis in a phase 2, randomized, placebo-controlled trial. J Am Acad Dermatol. 2019;80:1395-1402.

50. Menlo Therapeutics' successful phase 2 clinical trial of serlopitant demonstrates reduction of pruritus associated with psoriasis. https://www.globen ewswire.com/news-release/2018/12/10/1664253/0/ en/Menlo-Therapeutics-Successful-Phase-2-Clinic al-Trial-of-Serlopitant-Demonstrates-Reduction-of- 
Pruritus-Associated-with-Psoriasis.html. Accessed 10 Dec 2018.

51. Menlo Therapeutics announces results from a phase 2 trial of serlopitant for pruritus associated with atopic dermatitis. https://globenewswire.com/ne ws-release/2018/04/08/1466633/0/en/Menlo-Thera peutics-Announces-Results-from-a-Phase-2-Trial-ofSerlopitant-for-Pruritus-Associated-with-Atopic-Der matitis.html. Accessed 8 Apr 2018.

52. Di Fabio R, Alvaro G, Braggio S, et al. Identification, biological characterization and pharmacophoric analysis of a new potent and selective NK1 receptor antagonist clinical candidate. Bioorg Med Chem. 2013;21:6264-73.

53. Ratti E, Bettica P, Alexander R, et al. Full central neurokinin-1 receptor blockade is required for efficacy in depression: evidence from orvepitant clinical studies. J Psychopharmacol. 2013;27:424-34.

54. Trower MK, Fisher A, Upton N, Ratti E. Neurokinin1 receptor antagonist orvepitant is an effective inhibitor of itch-associated response in a Mongolian gerbil model of scratching behaviour. Exp Dermatol. 2014;23:858-60.

55. A randomised, double-blind, placebo-controlled study to evaluate the efficacy of two different dose levels of orvepitant (10 and $30 \mathrm{mg}$ ) compared with placebo on EGFRi-induced intense pruritus in oncology subjects (the "RELIEVE 1" study). https:// www.clinicaltrialsregister.eu/ctr-search/trial/2013002763-25/results. Accessed 16 Jul 2016.
56. Proof of concept of VLY-686 in subjects with treatment-resistant pruritus associated with atopic dermatitis. https://clinicaltrials.gov/ct2/show/NCT020 04041. Accessed 3 June 2015.

57. Heitman A, Xiao C, Cho Y, et al. Tradipitant improves worst itch and disease severity in patients with chronic pruritus related to atopic dermatitis. J Am Acad Dermatol. 2018;AB300:7788.

58. Evaluating the effects of tradipitant vs. placebo in atopic dermatitis. https://clinicaltrials.gov/ct2/ show/NCT03568331. Accessed 25 Feb 2019.

59. Chan SL, Jen J, Burke T, Pellissier J. Economic analysis of aprepitant-containing regimen to prevent chemotherapy-induced nausea and vomiting in patients receiving highly emetogenic chemotherapy in Hong Kong. Asia Pac J Clin Oncol. 2014;10:80-91.

60. Kramer MS, Cutler N, Feighner J, et al. Distinct mechanism for antidepressant activity by blockade of central substance $\mathrm{P}$ receptors. Science. 1998;281:1640-5.

61. Keller M, Montgomery S, Ball W, et al. Lack of efficacy of the substance $\mathrm{P}$ (neurokinin1 receptor) antagonist aprepitant in the treatment of major depressive disorder. Biol Psychiatry. 2006; 59:216-23.

62. Schank JR. The neurokinin-1 receptor in addictive processes. J Pharmacol Exp Ther. 2014;351:2-8. 